九州大学学術情報リポジトリ

Kyushu University Institutional Repository

\title{
A Revision of the Family Pselaphidae (Coleoptera) from Chejudo Is land, Korea
}

Nomura, Shuhe i

Lee, Chang Eon

https://doi.org/10.5109/2557

出版情報 : ESAKIA. 32，pp.59-80，1992-03-31. Entomological Laboratory，Faculty of Agriculture， Kyushu University

バージョン :

権利関係 : 


\title{
A Revision of the Family Pselaphidae (Coleoptera) from Chejudo Island, Korea ${ }^{1), 2}$
}

\author{
Shûhei NOMURA \\ Entomological Laboratory, Faculty of Agriculture, Kyushu University, \\ Pukuoka, 812 Japan \\ and \\ Chang Eon LEE \\ Department of Biology, College of Natural Sciences, Kyungpook National University, \\ Taegu, 702-701 Korea
}

\begin{abstract}
.
Pselaphids from Chejudo Island, Southern Korea comprises ten species, in which eight species are newly described together with illustrations of their important characters.
\end{abstract}

\section{Introduction}

The pselaphid fauna is so poorly known in southern part of Korea as Cho (1957) recorded only one species Poroderus armatus (Sharp) from this area. This report treats the Pselaphidae of Chejudo Island as the first part of the revision on the Pselaphidae of Southern Korea. It presents ten pselaphid species as follows, in which eight species are new to science.

\section{Subfamily BATRISINAE Reitter}

Tribe Batrisini s. str.

\section{Genus Basitrodes Jeannel}

Basitrodes Jeannel, 1958, Mém. Mus. nat. Hist., Paris, 18(1): 26; Newton \& Chandler, 1989, Field. Zool., N. S., (53): 33. Type species: Batrisus vestitus Sharp, by original designation.

1) Results from the Korea-Japan Co-operative Science Program on "The Evolution and Biogeography of the Insects in the East Asia". No. 6.

2) Contribution from the Entomological Laboratory, Faculty of Agriculture, Kyushu University, Fukuoka (Ser. 4, No. 40). 


\section{Basitrodes leptothoraxsp. nov.}

(Fig. 1A-C)

Male. Unknown.

Female. Length 2.1-2.2 mm. Width $0.7 \mathrm{~mm}$.

Body reddish brown, elongate and weakly broadened posteriorly.

Head slightly wider than long, clypeus broad, strongly projected anteriorly, limbate at its margin, frons depressed and glabrous at the median part, thickened and coarsely punctuate at both lateral parts, vertex weakly convex, minutely punctuate and shiny, with a pair of large tentorial pits. Eyes small, each ovoid, composed of about 15 facets. Antennae moniliform, reaching hind margin of pronotum, 1st segment thick and subcylindrical, 2nd ovoid, 3rd to 8th subequal in length, each subglobose, 9th to 10th thick, ovoid and transverse, 11th largest and ovoid, pointed at apex; relative lengths (widths) of each segment from base to apex are 2.0 (1.8): 1.5 (1.0): 1.0 (1.0): 1.0 (1.1): 1.0 (1.1): 1.0 (1.0): 1.0 (1.1): 1.0 (1.0): 1.3 (1.5): 1.5 (2.0): 3.2 (2.3).

Pronotum narrower than head, clearly longer than wide, widest at the middle, minutely punctuate and shiny with a shallow median longitudinal sulcus, a pair of lateral sulci and a pair of large crooked spines at anterior $2 / 5$. Elytra wider than long, weakly convex, sparsely punctuate, each elytron with 3 basidorsal foveae and 2 longitudinal sulci, outer sulcus reaching the middle of elytron. Legs elongate, thickened in femora, hind tibiae each slender, curved internally and thickened in apical $2 / 5$ with a spur at apex.
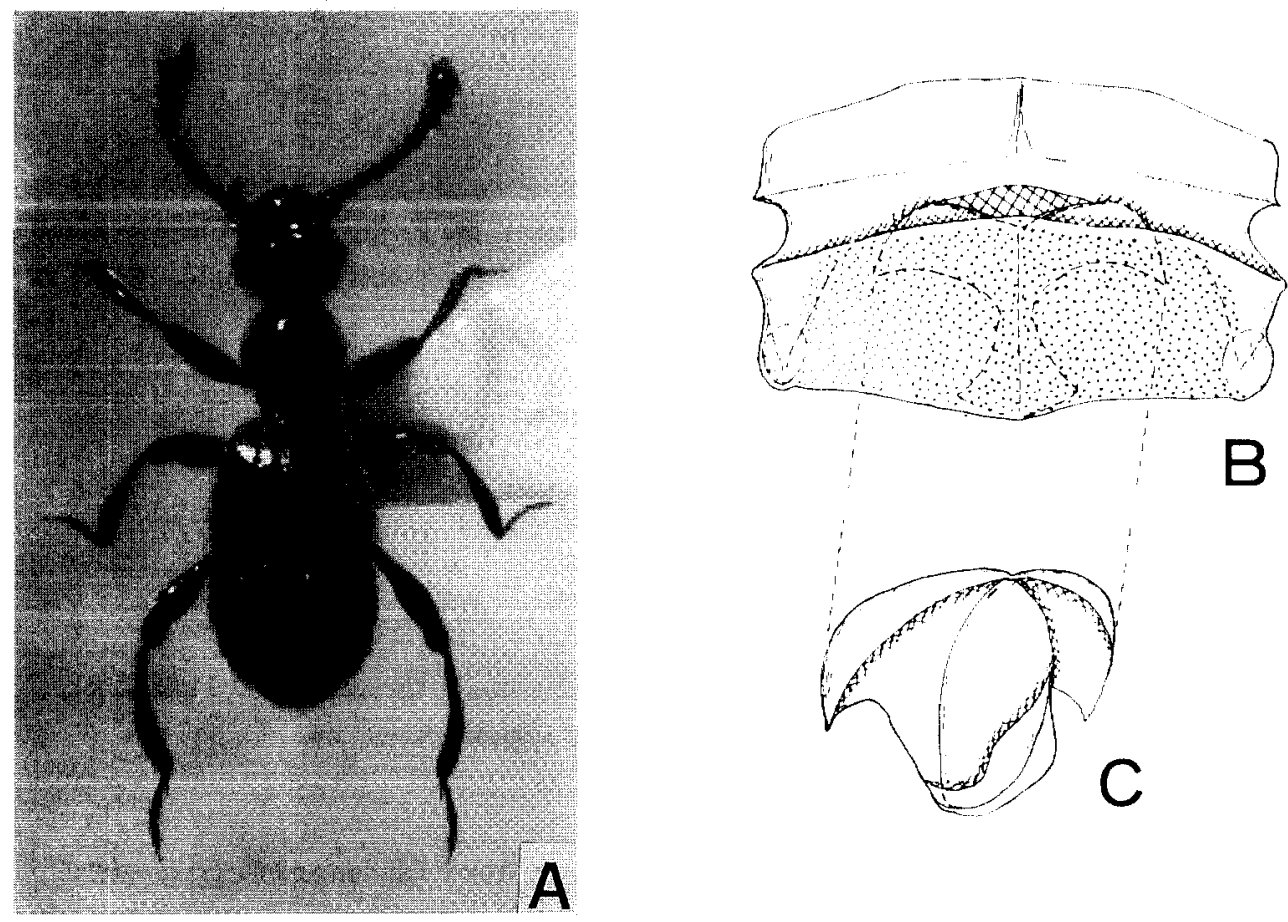

Fig. 1. Basitrodes leptothoraxsp. nov., female. A, dorsal aspect; B, 9th abdominal stemite in ventral view; $C$, genital plate. 
Abdomen as wide as elytra, rounded posteriorly, 4th segment largest and transverse, with a pair of short basimedian carinae, a pair of lateral carinae and 2 pairs of basidorsal foveae, each lateral carina obliquely running from outer basidorsal fovea to posterolateral corner of the segment, 5th to 6th short, subequal in length, 7th twice as long as 6 th, 8 th tergite transverse, rounded at apical margin, 8th sternite semicircular, flattened at median part. Female genitalia consisting of 9th sternite and genital plate, 9th stemite transverse and constricted in the middle part, genital plate T-shaped in ventral view, median wall ovoid in lateral view.

Remarks. This species is very similar to the genus Petaloscapus in having the well-projected clypeus, the frons with a pair of nodules on both sides and the pronotum with a pair of well-projected dorsomedian spines. Especially, it is very resemble with $\boldsymbol{P}$. sp. distributed in Tsushima Is. in having the elongate prothorax.

Distribution. Southern Korea (Chejudo Is.)

Holotype: female (deposited in Kyungpook Nat. Univ.), Yongshil, Mt. Hallasan, Chejudo Is., 24. vii. 1990, S. Nomura leg. Paratopotypes: 6 females, same data as holotype.

Genus Batriscenellus Jeanne1

Batriscenellus Jeannel, 1958, Mém. Mus. nat. Hit., Paris, (A), 18: 60; Newton \& Chandler, 1989, Field. Zool., N. S., (53): 34; Nomura, 1991, Esakia, Fukuoka, (31): 299. Type species: Batrisus fragilis Sharp, by original designation.

This genus is characterized by the first antennal segment with a semihyaline conical trichome at the external side as in the African genus Arthromelus Jeannel, and the Oriental Batrisiella Raffray.

Subgenus Batriscenellus s. str.

This nominotypical subgenus was redefined by Nomura, 1991 based on the following two characters: the sexual patch consisting of a pair of setiferous patches on the fifth abdominal segment, a fringe consisting of bold setae on the fifth segment, and the large and deep excavation including secretory setae on the sixth, and the basal bulb of the male genitalia with a well-projected articulate process.

\section{Batriscenellus vicarius Löbl, stat. nov.}

(Fig. 3A)

Batriscenellus japonicus vicarius Löbl, 1973, Ann. Zool., Warszawa, 30(9): 322; Kurbatov, 1990, Rev.

Ent. URSS, 69(1): 75; Nomura, 1991, Esakia, Fukuoka, (31): 302.

Remarks. This was described as a subspecies of B. japonicus (Sharp) by Löbl, 1973, but is better to rank a distinct species because of its unique characters, i. e. the large abdomen, the 7th to 8th abdominal sternites each with a pair of densely haired longitudinal carinae, and the male genitalia with a dorsally expanded basal bulb.

This species is distributed in broad area including two islands, Chejudo, Korea and Tsushima, Japan, and clearly separated from the ranges of $\boldsymbol{B}$. japonicus (Sharp) and allies. 
Distribution. Southern Korea (Chejudo Is.), Northern Korea, Russia (Primorye) and Japan (Tsushima Is.)

Specimens examined: 1 male and 2 females, Yongshil, Mt. Hallasan, Chejudo Is., 20. v. 1990, S. Nomura leg.; 3 males, same locality as above, 24. vii. 1990, S. Nomura leg.; 1 male 2 females, Kaewol Bridge, Mt. Hallasan, Chejudo Is., 26. vii. 1990, S. Nomura leg.; 5 males 7 females, Kuwanum Temple, Mt. Hallasan, Chejudo Is., 29. ix. 1990, S. Nomura leg.

\section{Subfamily GONIACERINAE Reitter}

\section{Tribe Tanypleurini Jeannel}

\section{Genus Machulkaia Löbl}

Machulkaia Löbl, 1964, Annot. zool. bot., (5): 1; Newton \& Chandler, 1989, Field., Zool., N. S., (53): 51. Type species: Machulkaia mirabilis Löbl, by monotypy.

The genus Machulkaia has a close relation with the genera Takaorites Jeannel, Nipponobythus Jeanne1 and Bithiotes Newton \& Chandler (renamed for the homonym Bythonesiotes, Jeannel, 1958) to form a genus-group. This genus-group is restricted to East Asia in their distribution, and is characterized by the frons with a sexual patch including secretory setae and the pronotum with an antebasal transverse sulcus.

\section{Machulkaia dolharubang sp. nov.}

(Fig. 2A-E, 3B )

Male. Length 1.8-1.9 mm. Width $0.8 \mathrm{~mm}$.

Body reddish brown, broadened posteriorly.

Head wider than long, nearly pentagonal, clypeus convex anterodorsally, limbate on anterior margin, frons widely excavated, median excavation transverse and deep with a pair of trichomes at median part of its hind margin, lateral excavations paired, ovoid and located on both posterolateral sides of the median excavation, each covered with short secretory setae on its bottom, vertex convex, shallowly depressed on anteromedian part, dorsal tentorial pits indistinct, tempora very broad and rounded. Eyes each small and ovoid, composed of about 15 facets. Antennae short, reached basal margin of elytra, bent outward at 7th segment, 1st segment large, slightly broadened posteriorly, flattened dorsally, 2nd to 3rd each ovoid, longer than wide, 4th to 7th subequal, each subglobose, 8th smallest and subglobose, 9th ovoid, longer than wide, 10th transverse, 11th largest, subcylindrical in basal part, subconical in apical part.

Pronotum as wide as head, wider than long, minutely punctuate and shiny with a transverse sulcus at posterior $1 / 4$. Elytra wider than long, narrowed anteriorly, nearly convex, sparsely punctuate. Legs elongate, hind tibiae slender, each swollen and curved internally in apical2/5.

Abdomen about as wide as elytra, 4th segment largest, slightly broadened posteriorly with a pair of subparallel basal carinae in basal 3/5, 5th to 7th short, subequal in length, 8th tergite transverse, arcuate on posterior margin, 8th sternite E-shaped, median stalk shorter than each lateral stalk, slightly broad- 
erred anteriorly, weakly curved rightward, hind part arcuate and pubescent, 9th sternite composed of a pair of slender sclerites.

Male genitalia weakly sclerotized and ovoid, parameres elongate, divergent apically, median lobe bulbous in basal part with an arrow-shaped sclerite in median part of apex, and with a pair of large projections on both lateral part of apex, each projection with beak-shaped sclerite. Endophallus composed of 4 large spines, 2 long spines each weakly curved, a short spine and an arcuate spine.

Female. Length 1.7-1.9 mm. Width 0.7-0.8 mm.

Similar to male excepting the following characters: Head trapezoid, broadened posteriorly, frons without excavation, broadly flattened and pubescent, with a weak transverse sulcus, vertex broad and weakly convex, with a longitudinal carina and a pair of distinct dorsal tentorial pits. Antennae slightly shorter than those of male, 7th segment normally subglobose.

Remarks. Machulkaia dolharubang sp. nov. is closely related to M. mirabilis Löbl described from Chekiang, Eastern China, but is distinguished from the latter by the each subglobose fourth to seventh antennal segments (each transformed in the latter species).

Distribution Southern Korea (Chejudo Is.).

Holotype: male (deposited in Kyungpook Nat. Univ.), Yongshil, Mt. Hallasan, Chejudo Is., 20. v. 1990, S. Nomura leg. Paratypes: 2 males and 1 female, same data as holotype; llmales 3 females, same locality as holotype, 24. vii. 1990, S. Nomura leg.; 1 male, Orimok, Mt. Hallasan, Chejudo Is., 20. v. 1990, S. Nomura leg.; 15 males 6 females, same locality as above, 27. vii, 1990, S. Nomura leg.; 7 males 1 female,
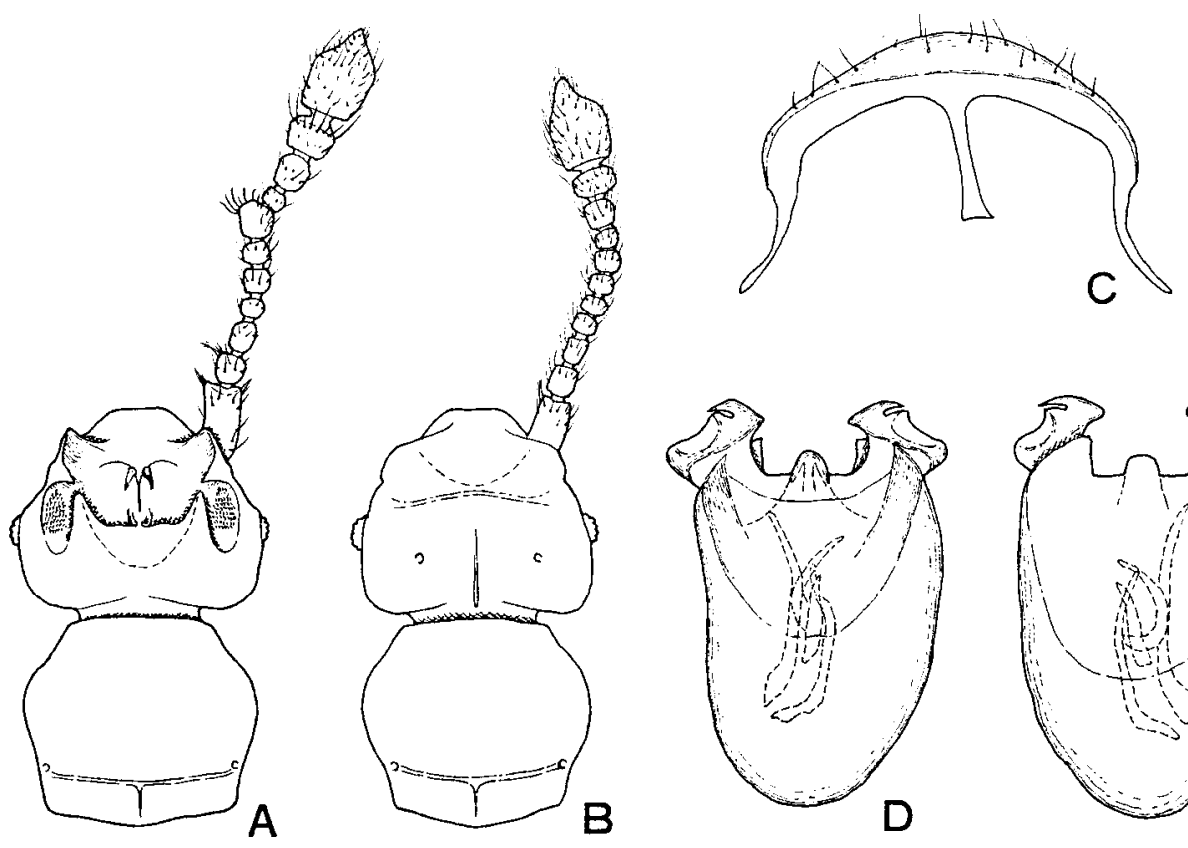

Pig. 2. Machulkaia dolharubang sp. nov. A, C-E, male; B, female. A, B, head and pronotum in dorsal view; $\mathrm{C}, 8$ th sternite in ventral view; D, male genitalia in ventral view, E, ditto in dorsal view. 
Kaewol Bridge, Mt. Hallasan, Chejudo Is., 26. vii. 1990, S. Nomura leg.; 3 males, Songp'anak, Mt. Hallasan, Chejudo Is., 28. ix. 1990, S. Nomura leg.; 1 male 1 female, Kuwanum Temple, Mt. Hallasan, Chejudo Is., 29. ix. 1990, S. Nomura leg.

\section{Genus Triomicrus Sharp}

Triomicrus Sharp, 1883, Trans. ent. Soc. London, 1883: 325; Raffray, 1904, Ann. Soc. ent. Fr., 73: 338; 1908, Psel., Gen. Ins.: 252; Jeannel, 1958, Mtm. Mus. nat. Hist., Paris, (A), 18: 69; Newton \& Chandler, 1989, Field., Zool., N. S., (53): 51. Type species: Bryaxis protervus Sharp, designated by Lucas, 1920.

Trimiomicrus ; Raffray, 1911, Psel., Coleopt. Cat., (27): 110; Newton \& Chandler, 1989, 1. c.: 52 (misspelling of Triomicrus)

The genus Triomicrus including seven species is recorded from Japan, China and Seychelles. The morphological similarity with the tribe Brachyglutini is suggested by Tanokuchi, 1985 and Ohishi, 1986. Thus the systematic position of this genus is doubtful It is very distinct in this tribe in having the ventrally folded seventh to eighth abdominal segments with asymmetrical sternites.

\section{Triomicrus penicilatus sp. nov.}

(Fig. 3C, 4A-G)

Male. Length $1.5 \mathrm{~mm}$. Width $0.6 \mathrm{~mm}$.

Body reddish brown and shiny, broadened and thickened in elytra and abdomen.

Head longer than wide, ovoid, minutely punctuate on dorsal surface, clypeus large, arcuate on anterior margin, frons broad, weakly concave at median part, with a median fovea at center, vertex slightly convex, weakly concave around both tentorial pits, ventromedian surface of genae with gular suture (extent genal area because of the reduction of the gular area) strongly expanded. Eyes well-developed and ovoid, each composed of about 20 facets. Antermae elongate, reaching base of elytra, 1st segment
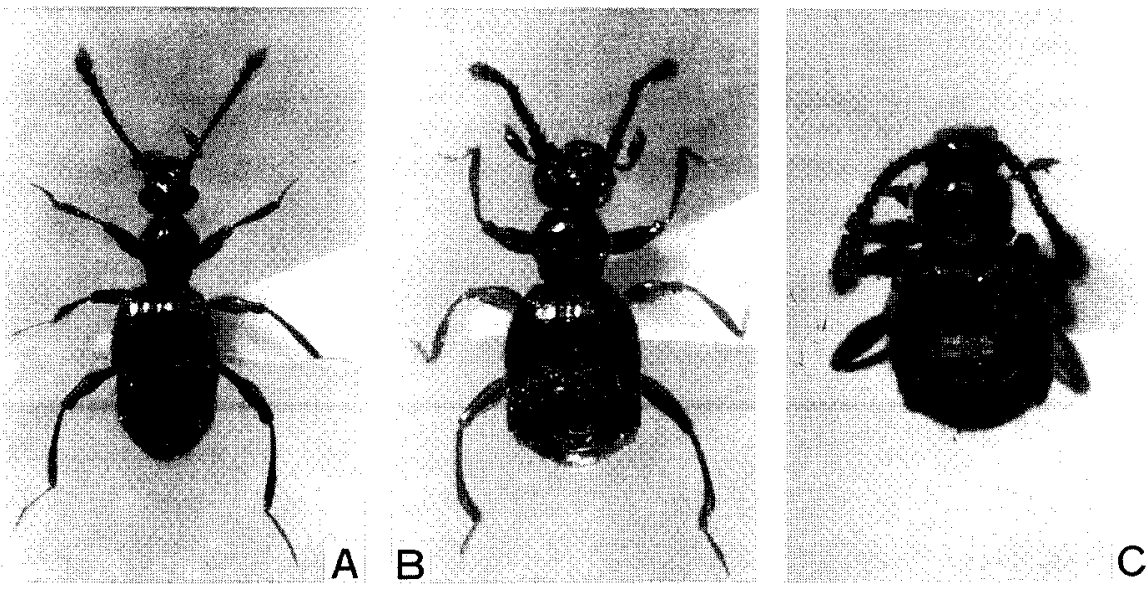

Fig. 3. A, Batriscenellus vicarius Löbl, male; B, Machulkaia dolharubang sp. nov., male; C, Triomicrus penicilatus sp. nov., female. 
thick and subcylindrical, 2nd to 7th each longer than wide, subcylindrical, 8th subglobose, 9th to 10th each slightly transverse and thickened distally, 11th largest, twice as long as wide, widest at apical3/7, weakly excavated at ventroapical part, with a short and subcylindrical process at antebasal part of inner side. Maxillary palpi long and elongate, 1st segment short and tubular, 2nd very long, swollen at basal 1/4 and apical 1/5, 3rd short, wider than 2nd, narrowed at base, thickened distally, with a long seta at outer part of its apex, 4th slightly shorter than 2 nd, as wide as 3 rd, fusiform and pedunculate, with a very short palpal spine.

Pronotum subglobose, widest at middle, with 3 antebasal foveae and minute and sparse punctures. Elytra slightly wider than long, moderately convex and weakly broadened posteriorly, each elytron with 2 basal foveae and 2 sulci, outer sulcus running from outer basal fovea to posterior 1/5. Metasternum broad, weakly concave at median part, with a pair of spines at just inside of metacoxae, each spine strongly curved anteriorly, acute and ciliate at apex. Legs long and slender, fore tibiae elongate, each thickened toward apex, with dense short setae in apical 1/5.

Abdomen short and rounded posteriorly, 4th segment largest, transverse and narrowed posteriorly,

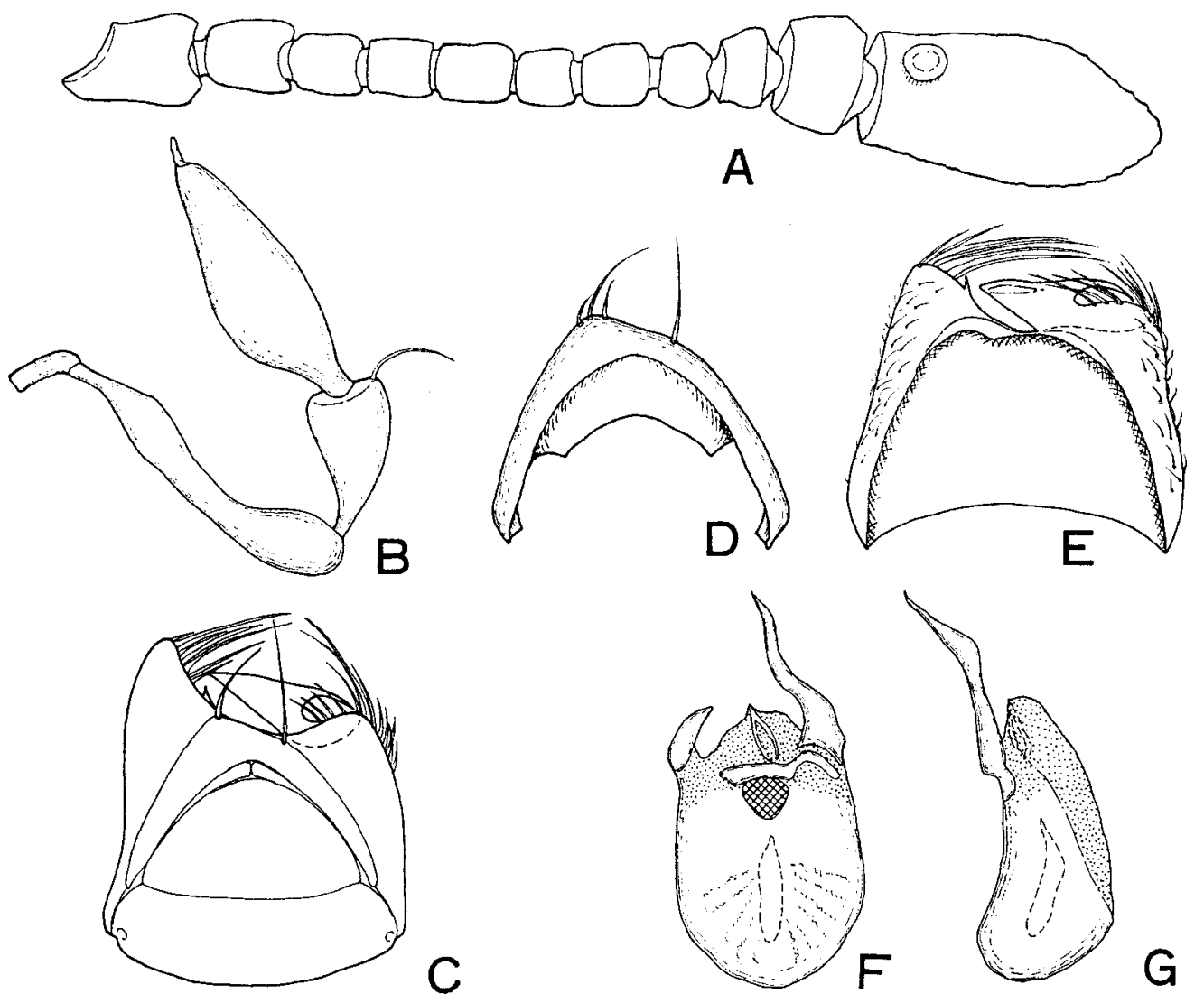

Fig. 4. Triomicrus penicilatus sp. nov., male. A, antenna; B, maxillary palpus; $\mathrm{C}$, 7th to 8th abdominal segments in ventral view; D, 7th stemite; E, 8th sternite; F, male genitalia in ventral view, $\mathrm{G}$, ditto, in lateral view. 
with 3 basal foveae, median fovea $1 / 10$ as wide as the segment, 5th to 6th short, 7th to 8th folded into ventral side, 7th tergite transverse and shortest, 7th sternite very large and asymmetrical, with a pair of apical processes, right process longer than the left, with very long setae at inner side of its apex, left process very broad, with long setae on apical side and with large and lamelar extension on inner side, 8th tergite almost triangular, 8th sternite attached to ventral side of 7th sternite, U-shaped and asymmetrical, expanded apically on its left side, with a pair of long and a few short setae, 9th sternite reduced into a pair of very short and slender sclerites, attached onto both sides of mate genitalia.

Male genitalia composed of well-sclerotized parameres and weakly sclerotized median lobe, parameres asymmetrical, right paramere large and elongate, broadened basally, acute at apex, weakly winded in ventral view, left paramere short, slightly narrowed apically, median lobe ovoid, with very small and ovoid basal foramen and endophallus, endophallus composed of 2 spines on its median line, apical spine short and fusiform, basal spine long and well-sclerotized.

Female. Length $1.5 \mathrm{~mm}$. width $0.6 \mathrm{~mm}$. Very similar to male but differs from the following characters: Eyes smaller than male, each composed of about 17 facets; 11th antennal segment without subcylindrical process; metasternum weakly convex, without spines on inside of metacoxae; 7 th to 8 th abdominal segments normal, 7th to 8th sternites each short, transverse and symmetrical.

Remarks. This new species T. peoicilatus is much similar to T. sublaevis Raffray in having the sparsely punctuate pronotum and the long hind legs. But it diiers from the latter by the longer right plate of the ninth sternite than the left (The left plate is longer than the right in T. sublaevis).

Distribution. Southern Korea (Chejudo Is.).

Holotype: male (deposited in Kyungpook Nat. Univ.), Kuwanum Temple, Mt. Hallasan, Chejudo Is., 29. ix. 1990, S. Nomura leg. Paratype: 1 female, Orimok, Mt. Hallasan, Chejudo Is., 27. vii. 1990, S. Nomura leg

\section{Tribe Bythinini Raffray}

\section{Genus Bryaxis Kugelann}

Bryaxis Kugelann, 1794, Neuest. Mag. Lieb. Ent., 1: 580; Raffray, 1904, Ann. Soc. ent. Fr., 73: 395; 1908, Col., Psel., Gen., Ins.: 275; 1911, Psel., Coleopt. Cat., (27): 115; Jeannel, 1958, Mtm. Mus. nat. Hist., Paris, (A), 18: 85; ICZN, 1969, Bull. Zool. Nom., 26:133 (type species designated); Besuchet, 1974a, Käf. Mitteleurop., 5: 338; Besuchet, 1974b, Misc. Zool., 3(4): 68; Newton \& Chandler, 1989, Field., Zool., (53): 47. Type species: Pselaphus bulbifer Reichenbach, designat ed by ICZN, 1969.

Arcopagus Leach, 1817, Zool. Misc., 3: 83; Jeannel, 1950, Col. Psel., Faun. Fr., 53: 231; Besuchet, 1974a, 1. c.: 338 (synonymized); 1974b, 1. c.: 68.

Kunzea Leach, 1826, Zool. Journ., 2: 448; Besuchet, 1974b, 1. c.: 68 (synonymized). Type species: Kunzea nigriceps Leach, by monotypy.

Picnogyne Gozis, 1886, Rect. syn. not. div., Herbii Montlucon, France: 16; Newton \& Chandler, 1989, Field., Zool., N. S., (53): 47 (synomynized). Type species: Bythinus pandellei Saulcy, by original designation. 
Bythoblethus Reitter, 1909, Faun. Germ., Stuttgart: 214; Jeannel, 1950, 1. c.: 231(as subg. of Arcopagus); 1958, 1. c.: 85 (as subg. of Bryaxis); Besuchet, 1974a, 1. c.: 338 (synonymized); 1974b, 1. c.: 68.

Megalobythus Jeannel, 1922, Bul. Soc. Stiinte din Cluj, 1: 232; Besuchet, 1974a, 1. c.: 338 (synomymized); 1974b, l. c.: 68. Type species: Megalobythus goliath Jeannel, by monotypy.

Embolobythus Jeannel, 1950, 1. c.: 231(as subg. of Arcopagus); Besuchet, 1974a, 1. c.: 338(synonymized); 1974b, 1. c.: 68. Type species: Bythinus curtisi Leach, by original designation.

Bythinites Jeannel, 1950, 1. c.: 231(as subg. of Arcopagus); Besuchet, 1974a, 1. c.: 338 (synonymized); 1974b, 1. c.: 68. Type species: Bythinus latebrosus Reitter, by original designation.

Bythinidius Jeannel, 1950, l. c.: 231(as subg. of Arcopagus); Besuchet, 1974a, 1. c.: 338 (synonymized); 1974b, 1. c.: 68. Type species: Bythinus crassicornis of authors ( = Bythinus glabricollis SchmidtGbbel, teste C. Besuchet)

Pyreneobythus Jeannel, 1950, 1. c.: 231(as subg. of Arcopagus); Besuchet, 1974a, 1. c.: 338 (synonymized); 1974b, 1. c.: 68. Type species: Bythinus pandellei Saulcy, by original designation.

Bythinomorphus Jeannel, 1950, 1. c.: 275; Besuchet, 1974a, 1. c.: 338 (synonymized); 1974b, 1. c.: 68. Type species: Bythinus fagei Jearmel, by original designation,

Parabythinus Jeannel, 1950, 1. c.: 220; Besuchet, 1974a, 1. c.: 338 (synonymized); 1974b, 1. c.: 68. Type species: Bythinus pyrenaeus Saulcy, by original designation.

Jugobythus Karaman, 1953, Act. Mus. Maced. Sci. Nat., Scopje, 1: 92 (as subg. of Arcopagus); Besuchet, 1974, 1. c.: 68; Newton \& Chandler, 1989, 1. c.: 6 (nomen nudum ).

Balkanobythus Karaman, 1954, Act. Mus. Maced. sci. nat., Scopje, 2: 83; Besuchet, 1974a, 1. c.: 338 (synonymized); 1974b, 1. c.: 68; Newton \& Chandler, 1989,1. c.: 6 (nomen nudum ).

Erichobythus Karaman, 1954, 1. c.: 81 (as subg. of Bythinites); Besuchet, 1974a, 1. c.: 338 (synonymized); 1974b, 1. c.: 68; Newton \& Chandler, 1989, 1. c.: 6 (nomen nudum ).

Bajulobythus Karaman, 1954,1. c.: 86 (as subg. of Arcopagus); 1957, Biol. Glasnik, 10: 171 (as subg. of Balcanobythus); Besuchet, 1974a, 1. c.: 338 (synonymized); 1974b, 1. c.: 68 (synonymized as nomen nudum).

Argiobythus Karaman, 1957, Biol. Glasnik, 10: 173; Besuchet, 1974a, 1. c.: 338 (synonymized); 1974b, l. c.: 68. Type species: Bythinus peloponnesius Reitter, by original description.

Balcanobythus Karaman, 1957, 1. c.: 170; Newton \& Chandler, 1989, 1. c.: 47 (synonymized). Type spe cies: Bythinus lokayi Machulka, by original designation.

Illyrobythus Karaman, 1957, 1. c.: 172; Besuchet, 1974a, 1. c.: 338 (synonymized); 1974b, 1. c.: 68. Type species: Bythinus longulus Kiesenwetter, by monotypy.

Plattibythus Karaman,1957, 1. c.: 173; Besuchet, 1974a, 1. c.: 338 (synonymized); 1974b, 1. c.: 68. Type species: Bythinus verrucipalpus Apferbeck, by original designation.

Parabythus Karaman, 1957, 1. c.: 174; Newton \& Chandler, 1989, 1. c.: 47 (misspelling of Parabythinus Jeannel).

Clavidius Karaman, 1957,1. c.: 168 (as subg. of Arcopagus); Besuchet, 1974a, 1. c.: 338 (synonymized); 1974b, 1. c.: 68; Newton \& Chandler, 1989, 1. c.: 6 (nomen nudum).

Dalmatobythus Karaman, 1957, 1. c.: 173 (as subg. of Argiobythus); Besuchet, 1974a, 1. c.: 338 (synony mized); 1974b, 1. c.: 68; Newton \& Chandler, 1989, 1. c.: 6 (nomen nudum).

Orientobythus Karaman, 1957, 1. c.: 168 (as subg. of Arwpagus); Besuchet, 1974a, 1. c.: 338 (synony mized); 1974b, 1. c.: 68; Newton \& Chandler, 1989, 1. c.: 6 (nomen nudum ). 
Iberobythus Franz, 1958, Eos, 34: 123; Besuchet, 1974a, 1. c.: 338 (synonymized); 1974b, 1. c.: 68 (synony mixed). Type species: Bryaxis crotchi Sharp, by original designation.

Arcobythus Jeamrel, 1958, 1. c.: 85 (subgenus). Type species: Bryaxis frontalis Jeamrel, by original designation.

Bythiniama Jeannel, 1958, Mtm. Mus. nat. Hist., Paris, (A), 18: 85 (subgenus).

Bythinopsidius Meggiolaro, 1960, Boll. Soc. ent. Ital., 90: 60; Besuchet, 1974a, 1. c.: 338 (synonymized);

1974b, 1. c.: 68 (synonymized). Type species: Bythinus pentagonoceras Stolz, by monotypy.

The genus Bryaxis is composed of many species and diversified all over the Palearctic Region. This genus is characterized by having the swollen first or second antennal segment in the male. According to Jeannel, 1958, the Oriental components of this genus are classified into three subgenera, Arcobythus Jeannel, Bythiniama Jeanne1 and Bythoblethus Reitter, in which the following two subgenus were found on Chejudo Island.

\section{Subgenus Bythiniama Jeanne1}

Bythiniama Jeamrel, 1958, Mém. Mus. nat. Hist., Paris, (A), 18: 85 (subgenus); Newton \& Chandler, 1989, Field., Zool., (53): 47. Type species: Bryaxis japonicus Sharp, by original designation.

This subgenus is characterized by the swollen second antennal segment which is sometimes having a well-projected secretory organ and by the smooth second to third segments of maxillary palpus. Though the subgenus was established on the Japanese species, it is widely distributed in East Asia.

\section{Bryaxis hallamontanus sp. nov.}

(Fig. 5A-F, 9A)

Homomorphous male. Length 1.3-1.4 mm. Width $0.6 \mathrm{~mm}$.

Body reddish brown, broadened in elytra and abdomen.

Head longer than wide, narrowed anteriorly, widest at just behind eyes, with dense and coarse punctures on dorsal surface, clypeus large, arcuate on anterior margin, frons narrowed, weakly concave, vertex slightly convex, with a pair of clear dorsal tentorial pits, postgenae short and slightly rounded. Eyes small, each ovoid and composed of $15-20$ facets. Antennae short, reaching posterior $1 / 3$ of pronotum, 1st segment thick and subcylindrical, weakly expanded internally, 2nd strongly swollen, with a secretory organ at basal $1 / 4$ on its inner surface, 3rd to 8th each very short, 4th to 6th subequal, each subglobose, 7th to 8th slightly transverse, 9th ot 10th thick and transverse, 11th largest, ovoid and conical at apex, relative length (width) of each segment from base to apex is $1.5(1.1): 1.5(1.3): 0.6(0.5): 0.5(0.5)$ $: 0.5(0.5): 0.5(0.5): 0.4(0.5): 0.4(0.5): 0.6(0.8): 0.7(1.1): 2.2$ (1.5). Maxillary palpi very long, slightly shorter than antennae, 1st segment very short and tubular, 2nd elongate, thickened distally and glabrous, 3rd short, subcylindrical, 4th largest, slightly longer than 2nd, densely pubescent and pedunculate at base, broadened distally in basal $1 / 3$, widest at basal $1 / 3$ then weakly narrowed apically in apical $2 / 3$, with a clear palpal spine at apex.

Pronotum wider than long, widest at anterior $2 / 5$, densely with coarse punctures, with a transverse sulcus and a pair of lateral foveae at posterior $\mathbf{1} / \mathbf{4}$. Elytra slightly wider than long, weakly convex, sparsely punctuate and moderately pubescent, broadened posteriorly, each elytron with 2 basal foveae and 2 
indistinct longitudinal sulci. Legs slender, hid tibiae weakly curved internally, each with a short and acute mucro at inner side of its apex.

Abdomen very short and broad, 4th segment largest, 4.5 times as wide as long, 5th to 8th tergites successively shortened and narrowed, 8th sternite transverse, broadened in median part, appointed at apex, 9th sternite divided into 3 sclerites, median sclerite very small and ovoid, lateral sclerites paired, each broad and quadrangular, with dorsally extending slender ventral strut.

Male genitalia nearly ovoid in ventral view, parameres ventroapically extending and curved internally, confluent in basiventral part, each with 2 apical setae, median lobe bulbous, with small basal foramen on ventral side, ovoid membranous part on basidorsal part and an apical process at apex of its apical lobe, endophallus consisting of a pair of elongate spines, each broadened basally, rounded at apex.

Heteromorphous male. Unknown.

Female. Length 1.3-1.4 mm. Width 0.5-0.6 mm.

Similar to male except for the following characters: Eyes smaller than in male, each composed of 6-7 facets. Antennae resembling to those of male, but 2nd segment smaller than 1st, elongately ovoid.

Remarks. B. hallamontanus belonging to the subgenus Bythiniama Jeanne1 is closely allied to $\boldsymbol{B}$. japonicus Sharp and $\boldsymbol{B}$. gracilipalpis Jeannel, but is separated from the former by the subglobose second antennal segment, and from the latter by the well-projected secretory organ on the segment.

Distribution. Southern Korea (Chejudo Is.).

Holotype: male (deposited in Kyungpook Nat. Univ.), Yongshil, Mt. Hallasan, Chejudo Is., 20. v. 1990, S. Nomura leg. Paratypes: 4 males 1 female, same locality as holotype, 24. vii. 1990, S. Nomura leg.;
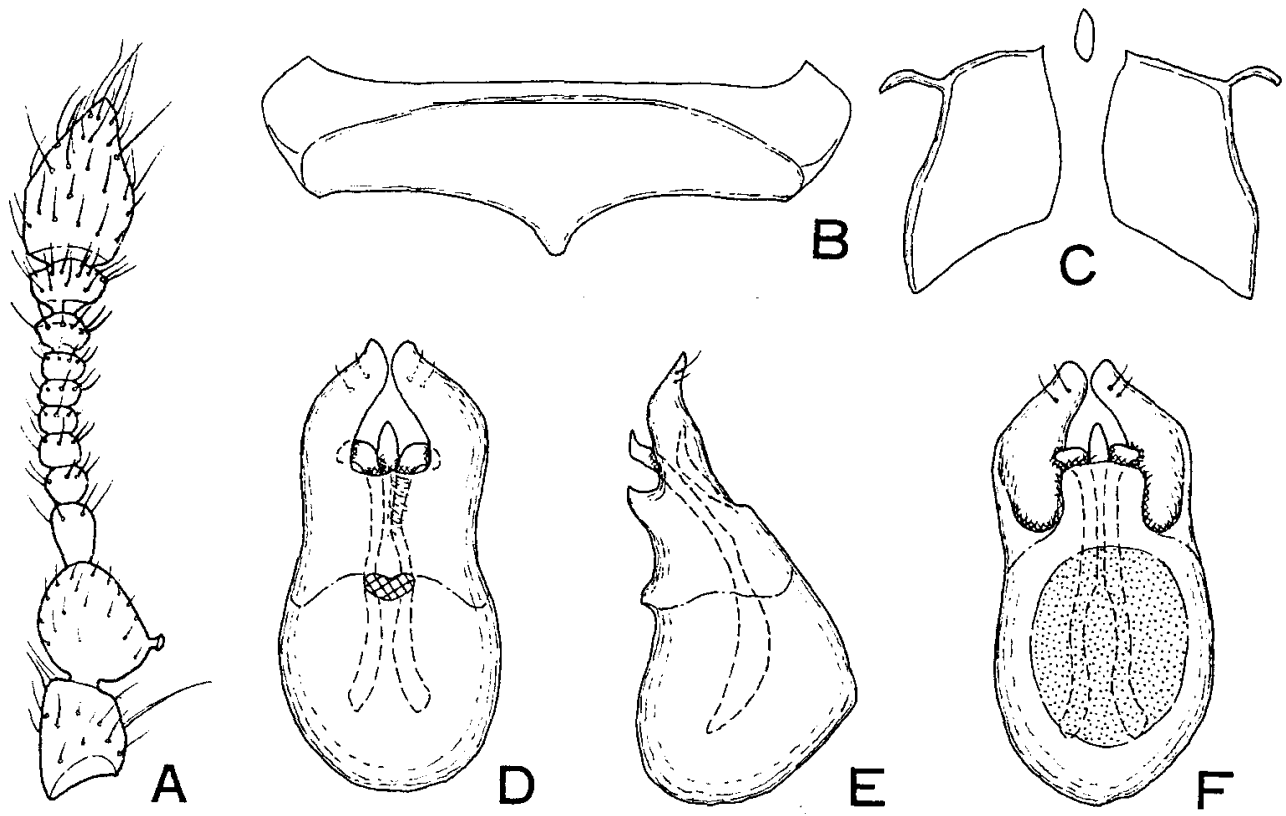

Fig. 5. Bryaxis hallamontanus sp. nov., male. A, antenna; B, 8th abdominal stemite; C, 9th sternite; D, male genitalia in ventral view; E, ditto, in lateral view, F, ditto, in dorsal view. 
4 males 6 females, Kaewol Bridge, Mt. Hallasan, Chejudo Is., 26. vii. 1990, S. Nomura leg.; 3 males 6 females, Orimok, Mt. Hallasan, Chejudo Is., 27. vii. 1990, S. Nomura leg.

\section{Subgenus Bythoblethus Reitter}

Bythoblethus Reitter, 1909, Farm. Germ., Stuttgart: 214; Jeannel, 1950, 1. c.: 231(as subg. of Arcopagus); 1958, Mém. Mus. nat. Hist., Paris, (A), 18: 85 (as subg. of Bryaxis). Type species: Arcopagus puncticollis Denny, designated by Jeannel, 1950.

This subgenus is distinguished from the other subgenera by the strongly swollen first antennal segment sometimes with a well-projected secretory organ and the ovoid or subcylindrical second segment. It differs from the nominotypical subgenus by lacking inner projection on the second antennal segment.

\section{Bryaxis corcanus sp. nov.}

(Fig. 6A-F, 7A-F,9B)

Heteromorphous male. Length $1.8 \mathrm{~mm}$. Width $0.7 \mathrm{~mm}$.

Body reddish brown, tarsi light brown, broadened posteriorly.

Head longer than wide, slightly constricted at middle, coarsely punctuate on dorsal surface, clypeus large, arcuately expanded anteriorly, frons narrow, concave at middle, vertex weakly convex, with a pair of clear dorsal tentorial pits just inside of eyes, postgenae broad, slightly rounded with long hairs, genae with a large transverse ventromedian process and excavated on both sides of the process. Eyes large, each ovoid and composed of about 30 facets. Antennae short, reaching anterior half of pronotum, 1st segment widest, strongly swollen internally, with a well-projected secretory organ at inner side of apical part, 2nd subglobose, 3rd ovoid, longer than wide, 4th to 8th subequal, each subglobose, as wide as 3rd, 9th slightly wider than 8th, 10th thick, transverse, 11th narrower than 1st, ovoid and pointed at apex, relative length (width) of each segment from base to apex is $2.2(1.7): 1.2(1.0): 1.0(0.7): 0.6(0.6): 0.6(0.6): 0.6(0.6)$ : $0.6(0.6): 0.6(0.6): 0.7(0.9): 1.0$ (1.2) : 2.5 (1.6). Maxillary palpi very long, slightly shorter than antennae, 1st segment very short, subcylindrical, 2nd slender, thickened distally, 3rd short, narrowed at base, 4th largest and pedunculate, 2.7 times as long as wide, widest at basal 1/3, palpal spine slender, about as 1/6 as long as 4th, acute at apex.

Pronotum slightly wider than long, roundly expanded on both sides, densely with coarse punctures, with a transverse sulcus at posterior $1 / 4$. Elytra slightly wider than long, broadened posteriorly, weakly convex and coarsely punctuate, each elytron with $\mathbf{2}$ basal foveae and $\mathbf{2}$ longitudinal sulci, outer sulcus short and indistinct. Legs very bold and robust, fore tibiae elongate, each deeply excavated internally in apical $2 / 7$, hind trochanters short, each with an acute and short denticle at posterior side of its apical part, hind tibiae swollen at apical $2 / 5$, each with an acute mucro at apex.

Abdomen short and broad, rounded posteriorly, 4th segment largest, about 5 times as wide as long, 5th to 8th segments successively shortened and narrowed, 8th sternite transverse, broadly expanded at posteromedian margin, 9th sternite composed of 3 sclerites, median sclerite small and ovoid, lateral sclerites paired, each nearly quadrangular, sclerotized and extended on basidorsal part.

Male genitalia well-sclerotized, parameres symmetrical, each narrowed apically, with 2 setae at apex, median lobe bulbous, with an ovoid basal foramen and a large membranous area on dorsal side, 
endophallus composed of slender 3 spines, 2 longer spines subequal in length, each weakly sinuate, a short spine located at left side of the others, incurved and acute at apex.

Homomorphous male. Length 1.6-1.7 mm. Width $0.7 \mathrm{~mm}$. Similar to heteromorphous male, but distinguished by the smaller body, the smaller and less expanded pronotum and the more slender legs.

Female. Length 1.6-1.7 mm. Width $0.7 \mathrm{~mm}$. Very similar to homomorphous male, but differs by the subcylindrical 1st antennal segment without secretory organ.

Remarks. B. coreanus belonging to the subgenus Bythoblethus is similar to B.affinis Sharp in the coarsely punctuate pronotum and strongly swollen first antennal segment, but is easily distinguished from it by the large body and the apically broadened secretory organ of the second antennal segment.

Distribution. Southern Korea (Chejudo Is.).

Holotype: male (deposited in Kungpook Nat. Univ.), Yongshil, Mt. Hallasan, Chejudo Is., 20. v. 1990, S. Nomura leg. Paratypes: 1 male 3 females, same data as holotype; 8 males 2 females, same locality as above, 24. vii. 1991, S. Nomura leg.; 5 males 4 females, Kaewol Bridge, Mt. Hallasan, Chejudo Is., 26. vii. 1990, S. Nomwa leg.; 2 males 2 females, Orimok, Mt. Hallasan, Chejudo Is., 27. vii. 1990, S. Nomura leg.; 3 males 8 females, Kuwanun Temple, Mt. Hallasan, Chejudo Is., 29, ix. 1990, S. Nomura leg.
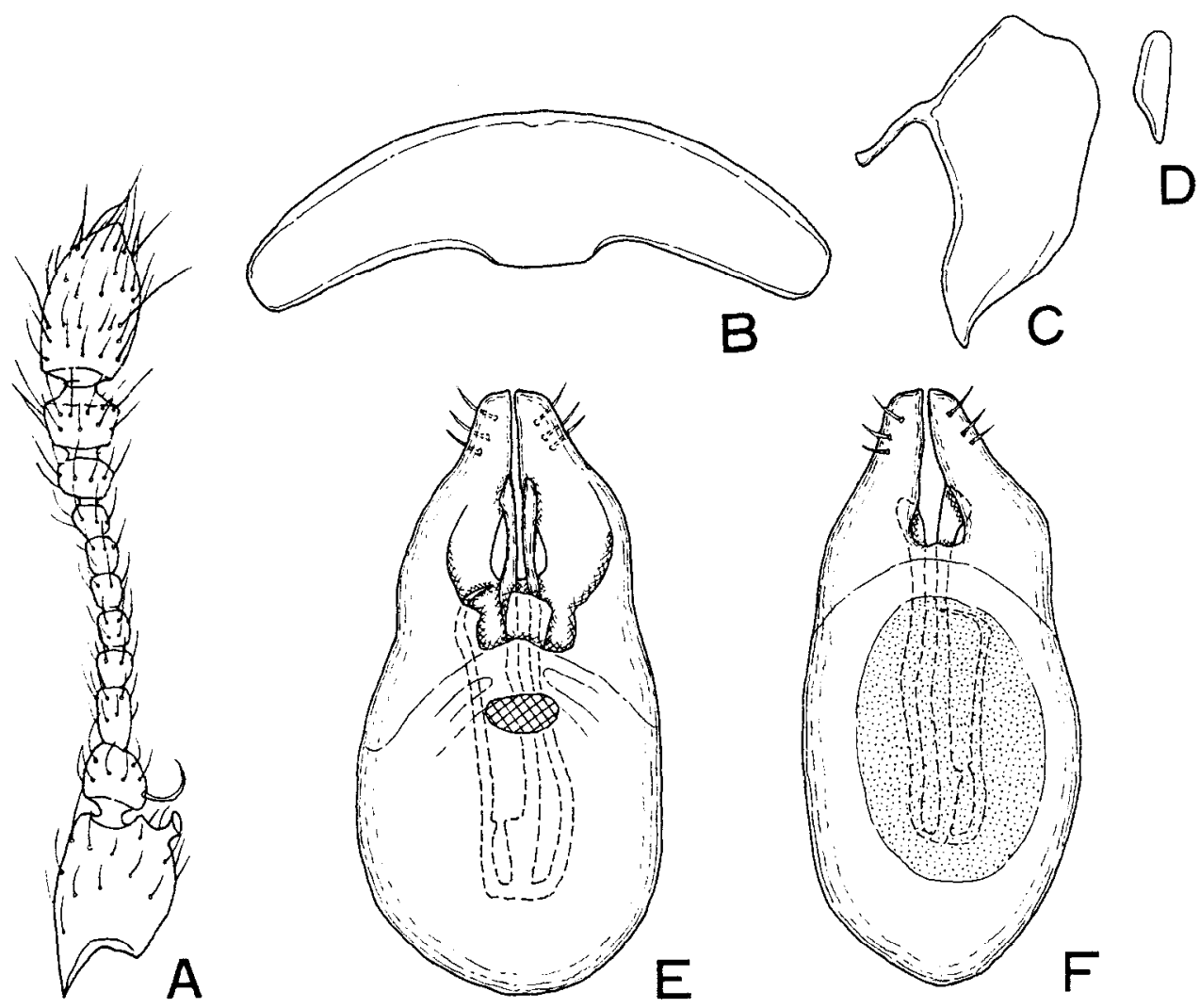

Fig. 6. Bryaxis coreanus sp. nov., male. A, antenna; B, 8th abdominal sternite; C, 9th sternite, lateral sclerite; D, ditto, median sclerite; E, male genitalia in ventral view; F, ditto, in dorsal view. 

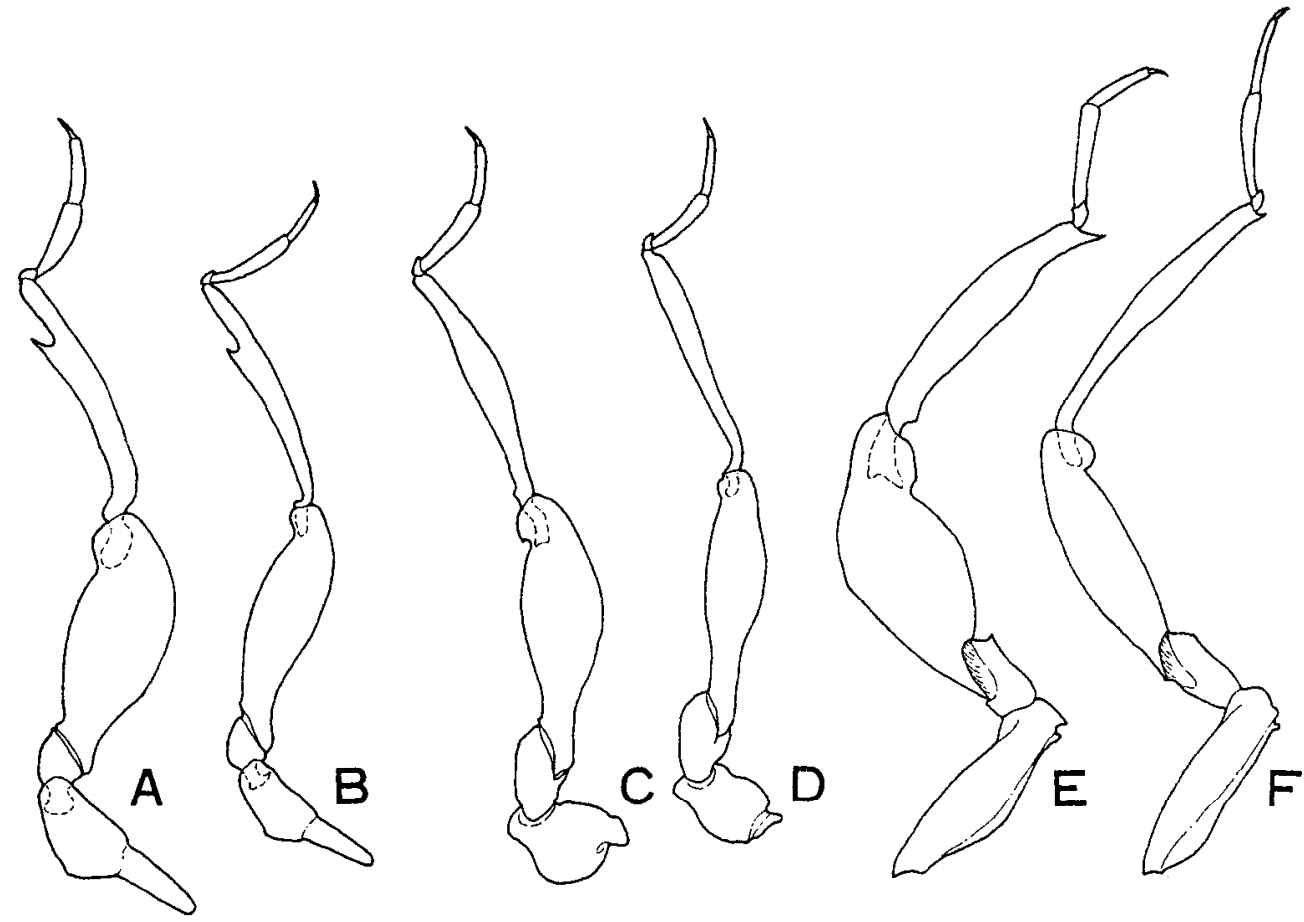

Fig. 7. Bryaxis coreanus sp. nov. A, C, E, heteromorphous male; B, D, F, homeomorphous male. A, B, fore leg; C, D, mid leg, E, F, hind leg.

Tribe Tychini Raffray

Germs Tychus Leach

Tychus Leach, 1817, zool. Misc., 3: 84; Aubé, 1833, Psel. Mon.: 42; Reitter, 1881, Verh. z. b. Ges. Wien, 31: 454; Guillebeau, 1888, Rev. Ent., 7: 368, Peyerimhoff, 1904, Abs., 30: 169; Raffray, 1904, Ann. Soc. ent. Fr., 73: 412; 1908, Col., Psel., Gen., Ins.: 291; 1911, Psel., Coleopt. Cat., (27): 128; Dodero, 1919, Ann. genova, 48: 225; Jeannel, 1950, Col. Psel., Farm. Fr., 53: 332; 1956, Mém Mus. nat. Hist., Paris, 14: 131; 1958, ibid, (Sér. A, Zool.), 18(1): 105; Chandler, 1988, Trans. Amer. ent. Soc., 114: 154; Newton \& Chandler, 1989, Field. Zool., N. S., (53): 53. Type species: Pselaphus niger Reichenbach, by monotypy.

Tychoides Karaman, 1955, Acta Mus. mac. sci. nat., Skopje, 3: 124.

Tychus dichotomus sp. $n w$.

(Fig. 8A-G) 
Male. Length $1.4 \mathrm{~mm}$. Width $0.5 \mathrm{~mm}$.

Body reddish brown and shiny, maxillary palpi light brown, broadened posteriorly, covered with longhairs.

Head slightly longer than wide, narrowed anteriorly, clypeus very short, invisible in dorsal view, frons heightened to make a pair of antennal tubercles, vertex convex, with a pair of small dorsal tentorial pits just inside eyes, postgenae narrow and rounded. Eyes small, each ovoid and composed of about 20 facets. Antennae elongate, 1st to 2nd segments thick and subcylindrical, 3rd to 7th moniliiorm, each ovoid and transverse, 8th to 10th subcylindrical, 9th and 10th distinctly thick, 11th largest, subcylindrical in basal part, subconical in apical part, relative length (width) of each segment from base to apex is 1.3 (1.0) : 1.0 (0.9) : 0.7 (0.8) : $0.6(0.7): 0.5$ (0.7) : 0.5 (0.8) : $0.6(0.9): 0.9$ (1.2) : 1.0 (1.5) : 2.5 (1.7). Maxillary palpi short, 1st segment short and tubular, 2nd elongate, thickened distally, 3rd nearly triangular, roundly expanded on its inner side, slightly expanded on outer side, 4th largest and ovoid, twice as long as wide.

Pronotum transverse, roundly expanded laterally, almost glabrous on dorsal surface, with a pair of basilateral foveae at basal 1/7. Elytra wider than long, weakly broadened posteriorly, sparsely punctuate, each elytron with 2 large basal foveae and 2 shallow and subparallel sulci, outer sulcus running from outer fovea to middle of elytron. Legs slender and short.

Abdomen short and broad, rounded posteriorly, 4th segment largest, with a transverse basimedian depression and well-demarcated paratergites, 5th to 8th successively shortened and narrowed distally, 8th tergite trapezoid, weakly convex, 8th sternite very short, and transverse, 9th sternite divided into 3 sclerites, median sclerite nearly pentagonal, lateral sclerites paired, each trapezoid with a long ventral

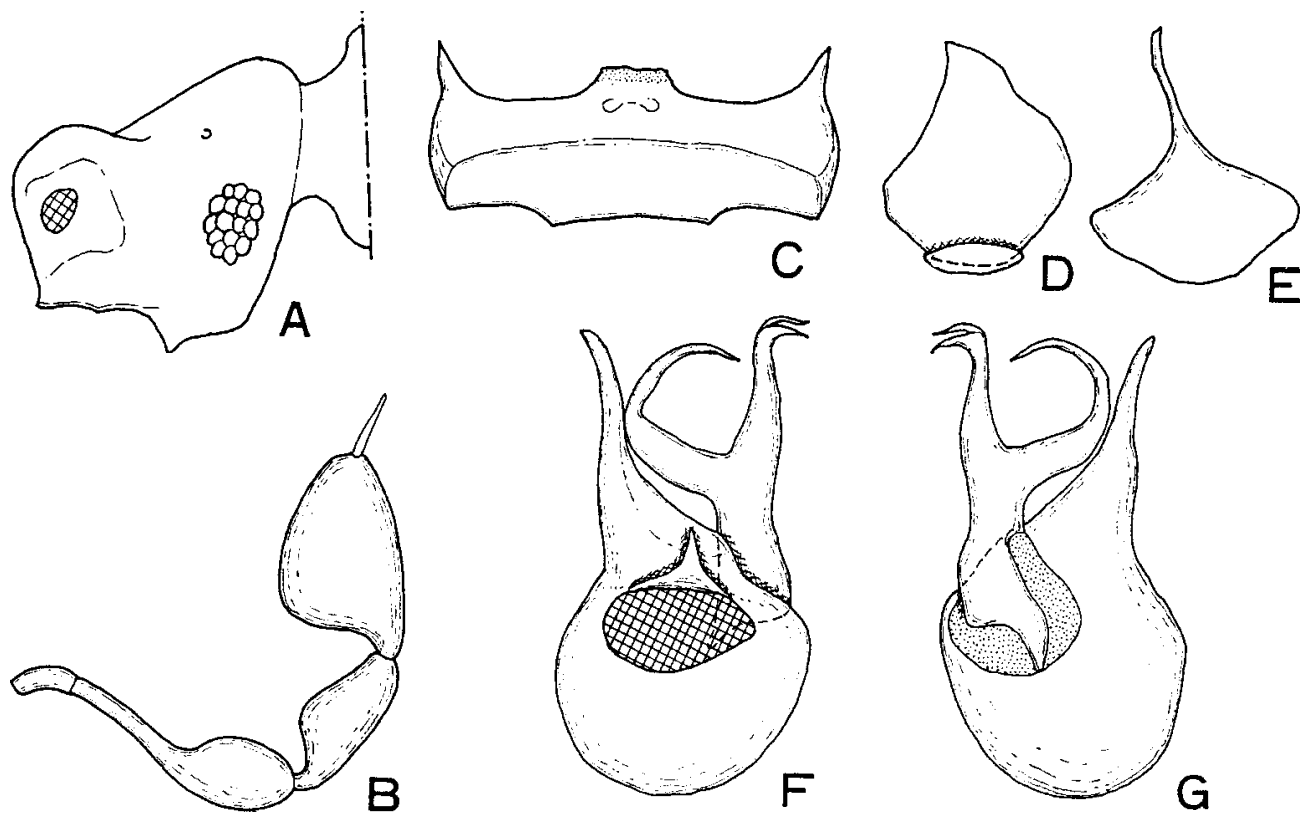

Fig. 8. Tychus dichotomus sp. nov., male. A, cranium in lateral view; B, maxillary palpus; C, 8th abdominal stemite; D, 9th abdominal stemite, median sclerite; E, ditto, lateral sclerite; F, male genitalia in ventral view, $\mathrm{G}$, ditto, in dorsal view. 
strut at basiventral part.

Male genitalia consisting of only median lobe, median lobe bulbous on basal part, with a large and ovoid basal foramen, a short spine attached at apical margin of the basal foramen and an elongate apical spine, dorsal apophysis located on right side of the apical spine, bifurcate and slender with 2 acute spines, right spine hook-shaped rightward at apex, left spine arcuately curved outward to closed to right spine at apex.

Female. Length $1.4 \mathrm{~mm}$. Width $0.5 \mathrm{~mm}$. Very similar to male excepting the membranous and externally invisible ninth abdominal stemite.

Remarks. This new species is similar to the other species of this genus, but it differs by the bifurcate dorsal apophysis of the median lobe of male genitalia, which is having a hooked right spine and an arcuately curved left spine.

Distribution. Southern Korea (Chejudo Is.).

Holotype: male, (deposited in Kyungpook Nat. Univ.) Yongshil, Mt. Hallasan, Chejudo Is., 20. v. 1990, S. Nomura leg. Paratypes: 1 female, same locality as holotype, 24. vii. 1990, S. Nomura leg.; 1 female, Kaewol Bridge, Mt. Hallasan, Chejudo Is., 26. vii. 1990, S. Nomura leg.; 1 male 2 females, Orimok, Mt. Hallasan, Chejudo Is., 27. vii. 1990, S. Nomura leg.

\section{Genus Atychodea Reitter}

Atychodea Reitter, 1884, Verh. Kais.-Königl. Zool.-Bot. Ges., Wien, 33: 412; Raffray, 1904, Arm. Soc. ent. Fr., 73: 418; 1908, Col., Psel., Gen., Ins.: 294; 1911, Psel., Coleopt. Cat., (27): 132, Chandler, 1988, Trans. Amer. ent. Soc., 114: 156; Newton \& Chandler, 1989, Field. Zool., N. S., (53): 53.

This genus is very characteristic in the tribe Tychini for the elytra each with three basal foveae and the clearly symmetrical aedeagus. Chandler (1988) regarded the feature as an ancestral character of this tribe. Whereas this genus has ever been known only in Borneo, it is also distributed in Northern Asia.

\section{Atychodea insulicala sp. nov.}

(Fig. 9C, 10A-H)

\section{Male. Length $1.7 \mathrm{~mm}$. Width $0.6 \mathrm{~mm}$.}

Body reddish brown, maxillary palpi light brown, weakly broadened in elytra and abdomen.

Head longer than wide, narrowed anteriorly, clypeus very short, invisible in dorsal view, frons strongly expanded to form a pair of antermal tubercles, constricted behind the tubercles, vertex slightly convex, dorsally, strongly convex posteriorly, minutely punctuate, with a pair of dorsal tentorial pits at anterior level of eyes, distant from eyes about 3 oceller diameters, postgena large and flat, covered with long hairs, ventral hook located at center of ventral surface of head, acute and arcuately curved proximally. Eyes large and convex, each ovoid and composed of about $\mathbf{2 0}$ facets. Antennae elongate, reaching hind margin of pronotum, 1st to 2 nd segments thick and each subcylindrical, 3rd to 7th subequal in width, moniliform, 8th to 10th successively enlarged, each ovoid, 11th largest, nearly ovoid in basal part, pointed at apex, relative length (width) of each segment from base to apex is $1.5(1.1): 1.1(1.0): 1.0(0.8): 0.8(0.8): 0.9$ $(0.8): 0.8(0.8): 0.8(0.8): 0.7(0.9): 1.2(1.2): 1.2(1.5): 3.1$ (2.0). Maxillary palpi very long, 1 st segment 
short and tubular, 2nd elongate, strongly thickened on apical part, 3rd short, very slender at base, inner margin angularly expanded, outer margin weakly concave, with a short seta at apex, 4th widest, strongly narrowed at base, strongly broadened at basal $1 / 3$, then weakly narrowed apically, palpal spine long and slender, $1 / 3$ times as long as 4 th segment.

Pronotum slightly wider than long, widest at basal $4 / 9$, roundly expanded on both sides, convex and coarsely punctuate on dorsal surface, with a pair of lateral foveae at basal 1/4. Elytra wider than long, weakly convex and coarsely punctuate, slightly broadened posteriorly, each elytron with 2 basal foveae and 2 longitudinal sulci, outer sulcus running from outer basal fovea to middle of elytron. Metasternum broad, with a pair of ventral projections between meso- metacoxae. Legs slender, hind trochanters short, each with a ventral projection at basal part.

Abdomen weakly narrowed posteriorly, 4th segment largest, with 2 pairs of dorsolateral foveae and a dorsomedian depression, 5th slightly shorter than 4th, transverse, 6th as long as 5th, narrower than 5th, 7th tergite semicircular in dorsal view, slightly longer than 6th, 8th tergite clearly smaller than the foregoing segment transverse in external view, 8th sternite angularly excavated on apical margin, with a pair of internal extensions on both lateral part, a pair of ventromedian foveae and a membranous sac (rudiment of the defensive gland) at basimedian margin, 9th stemite composed of 3 sclerites, median sclerite small and nearly ovoid, lateral sclerites paired, each elongate, slender on basal part and broadened distally.

Male genitalia symmetrical, parameres paired, each elongate and divided into basal sclerite and apical membrane, basal sclerite weakly broadened distally, apical membrane attached to proximal side of apex of basal sclerite, with 3 long setae at apex; median lobe consisting of basal bulb and dorsal apophysis, basal bulb extended and narrowed distally, bifurcate and broadened at apex, with a large and transverse basal foramen and a large and well-projected ventral process, dorsal apophysis narrowed on middle part, acutely projected just in front of apex of basal bulb.

Female. Length 1.5-1.6 mm. Width $0.6 \mathrm{~mm}$. Similar to male, differs in the following features: Eyes much smaller than in male, each composed of about 10 facets, pronotum almost flat between meso-
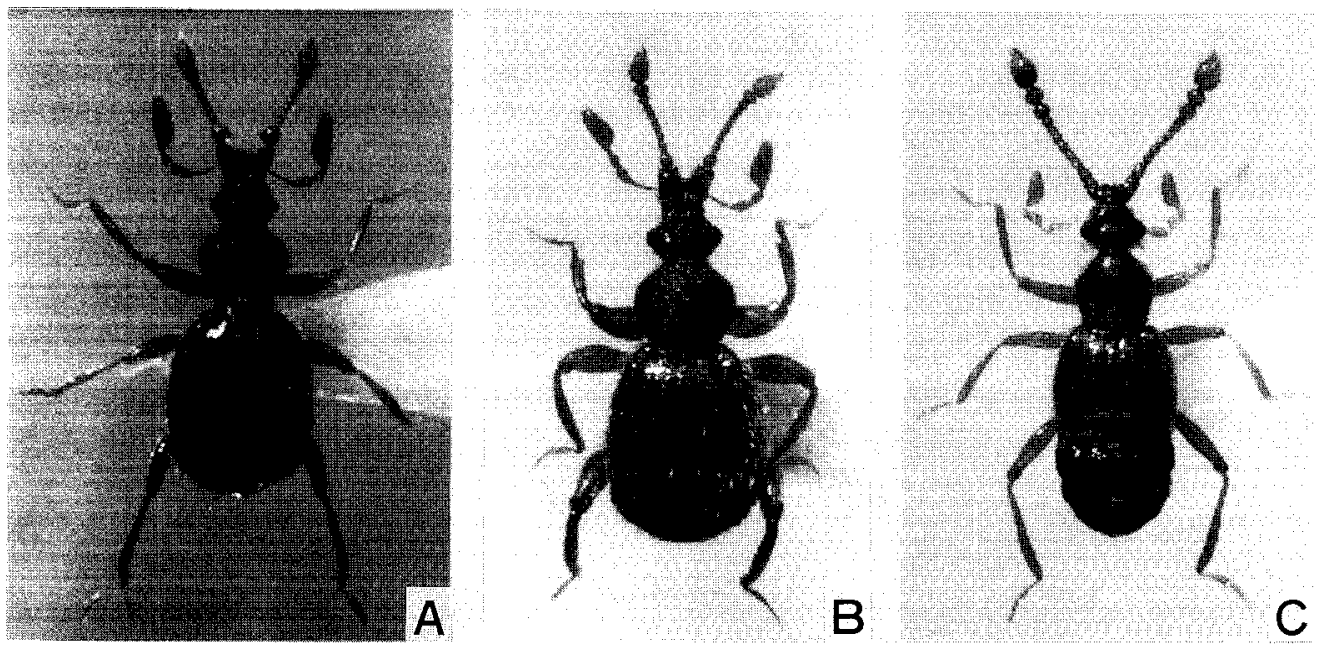

Fig. 9. A. Bryaxis hallamontanus sp. nov., homeomorphous male; B, B. coreanus sp. nov., heteromorphous male; C, Atychodea insulicola sp. nov., male. 


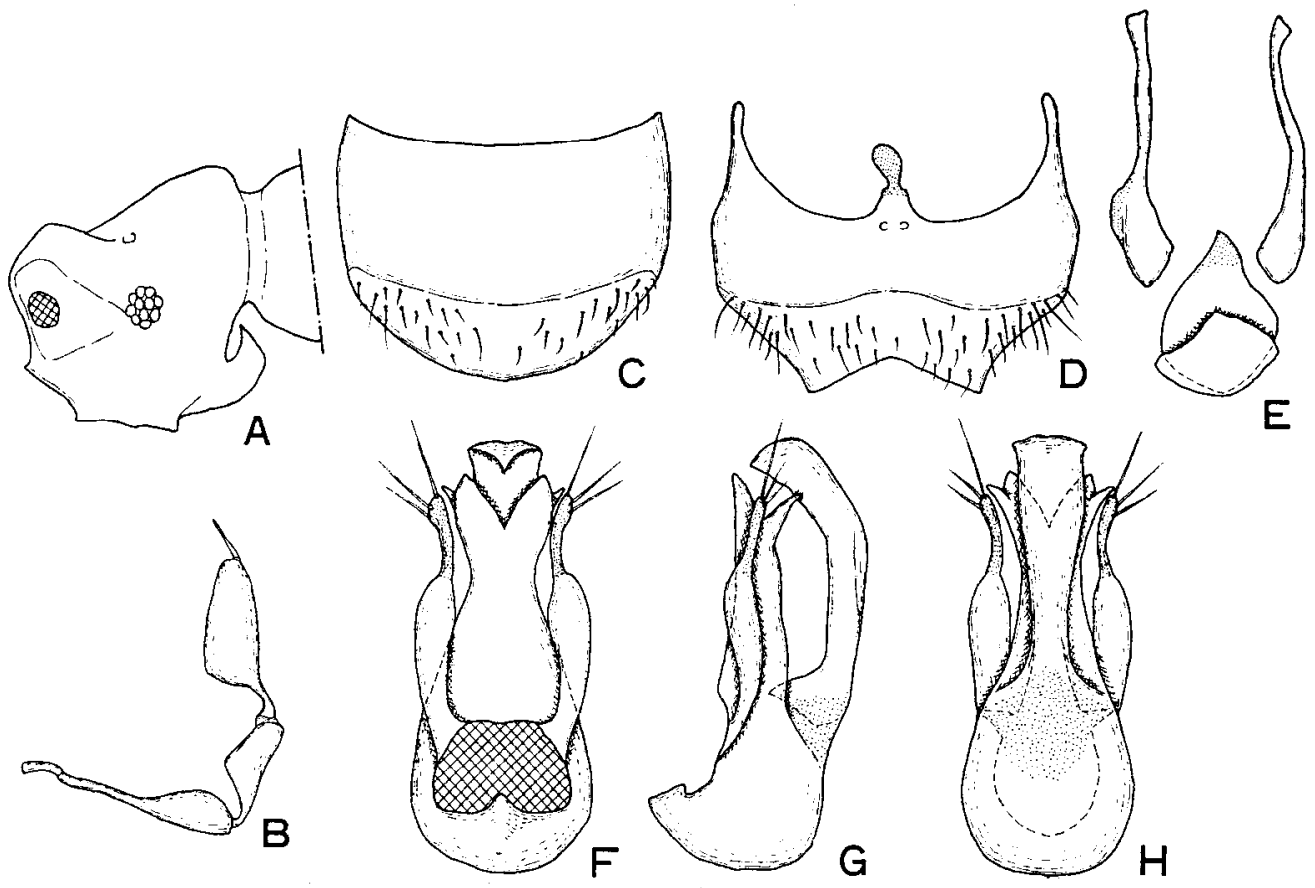

Fig. 10. Atychodea insulicola sp. nov., male. A, cranium in lateral view; B, maxillary palpus; C, 8th abdominal tergite; D, 8th sternite; E, 9th sternite; F, male genitalia in ventral view; $\mathrm{G}$, ditto, in lateral view; $\mathrm{H}$, ditto, in dorsal view.

metacoxae, hind trochanters flat on basal part, 8th sternite arcuate on apical margin, 9th sternite membranous.

Remarks. This Korean species is very distinct in this genus in having the arcuately curved hook at the middle of the ventral surface of the head. It is also similar to Tychus dichotomus in appearance, but the body is larger, the third palpal segment larger and angular and the elytra has three pairs of foveae.

Distribution. Chejudo Is.

Holotype: male (deposited in Kyungpook Nat. Univ.), Yongshil, Mt. Hallasan, Chejudo Is., 20. v. 1990, S. Nomura leg. Paratypes: 1 female, same locality as holotype, 24. vii. 1990, S. Nomura leg.; 1 female, Kaewol Bridge, Mt. Hallasan, Chejudo Is., 26. vii. 1990, S. Nomura leg.; 1 male 2 females, Orimok, Mt. Hallasan, Chejudo Is., 27. vii. 1990, S. Nomura leg.

\section{Subfamily PSELAPHINAE}

Tribe Pselaphini s. str.

Genus Dicentrius Reitter 
Dicentrius Reitter, 1882, Verh. Naturf. Ver. Brünn, 20: 208; Raffray, 1904, Arm. Soc. ent Fr., 73: 452; 1908, Col. Psel., Gen. Ins.: 308; 1911, Psel., Coleopt., Cat., (27): 139; Newton \& Chandler, 1989, Field., Zool., N. S., (53): 62. Type species: Pselaphus merklii Reitter, by monotypy.

Pselaphogenius Reitter, 1910, Wien. ent. Zeit., 29: 155 (subgenus); Jeannel, 1950, Col. Psel., Faun. Fr., 53: 421 (subgenus); Besuchet, 1961, Eos, 37(3): 257 (ranked up to the genus); Newton \& Chan dler, 1989, 1. c.: 62 (synonymized). Type species: Pselaphus quadricostatus Reitter, designated by Jeannel, 1950.

Pselaphodinus Jeannel, 1950, Col. Psel., Farm. Fr., 53: 389 (subgenus); Besuchet, 1961, 1. c.: 257 (synonymized). Type species: Pselaphus longipalpis Kiesenwetter, by original designation.

\section{Dicentrius sp.}

(Fig. 11A)

Remarks. Only a female was collected from Chejudo Island, and it is impossible to identify it into species.

specimen examined: 1 female, Yongshil, Mt. Hallasan, Chejudo Is., 24. vii. 1990, S. Nomura leg.

\section{Subfamily CLAVIGERINAE}

Tribe Clavigeriai sensu Besuchet, 1991

\section{Genus DiartigerSharp}

Diartiger Sharp, 1883, Trans. ent Soc. London, 1883: 329; Raffray, 1904, Arm. Soc. ent Fr., 73: 585; 1908, Col. Psel., Gen. Ins.: 437; 1911, Psel., Coleopt., Cat., (27): 176; Jeannel, 1958, Mém. Mus. nat. Hist., Paris, Sér. A, Zool., 18(1): 125; Newton \& Chandler, 1989, Field. Zool., N. S., (53): 64. Type species: Diartiger fossulatus Sharp, designated by Lucas, 1920.

Microdiartiger, K. Sawada, 1964, Ent. Rev. Japan, 17: 12; Besuchet, 1986, Rev. Suisse Zool., 93(1): 263 (synonymized). Type species: Microdiartiger japonicus Sawada, by monotypy.

Coiffaitius, Karaman, 1969, Biol. Gallo-Hellenica, 2: 50; Besuchet, 1986, 1. c.: 263 (synonymized). Type species: Coiffaitius ispartae Karaman, by monotypy.

\section{Diartiger dentipes sp. nov.}

(Fig. 11B, 12A-E)

Male. Length 2.0-2.1 mm, Width $0.8 \mathrm{~mm}$.

Body reddish brown, narrowed anterior\& broadened and rounded posteriorly.

Head longer than wide, rectangular in dorsal view, clypeus very short, slightly broadened anteriorly, nearly arcuate on anterior margin, frons strongly convex, densely punctuate, with a pair of dorsal tentorial pits just behind eyes, tempora subparallel-sided. Eyes convex, each ovoid, and composed of about 20 facets. Antennae short and 3-segmented, 1st segment short and cylindrical, 2nd elongate, about as wide as 1st, narrowed basally, 3rd largest, slightly longer than 1st + 2nd, gradually thickened distally, 
truncate at apex.

Pronotum subglobose and densely punctuate, with a basimedian fovea at basal $\mathbf{1 / 5}$ and a shallow longitudinal depression around basimedian fovea. Elytra nearly trapezoid, weakly convex and angularly emarginate on anterior margin, each elytron with a large fringe at outer part of hind margin. Metasternum flattened on posteromedian part, covered with long hairs along ventromedian line. Legs short and slender, sparsely setose, mid trochanters large, each broadened distally with a large and truncate spine on ventral side, mid femora weakly incurved, each with a small denticle at basal $\mathbf{1} / 4$, mid tibiae flattened on both inner and outer sides, each with a small denticle at apical 2/5 of inner side.

Abdomen widest, consist of composite tergites (3rd to 6th), 7th and 8th tergites on dorsal side and 3rd to 8th sternites on ventral side, composite tergites predominantly large, shiny and sparsely setose, deeply concave in basal part and convex on posterior part, with 3 pairs of trichomes and 2 pairs of short sulci, outer trichome nearly triangular, located at basilateral corner, middle trichome just behind elytral trichome, hook-shaped, inner trichome transverse, located between fore and hind pairs of sulci, 7th tergite short and transverse, arcuate on anterior margin 8th tergite nearly circular.

Male genitalia strongly sclerotized and symmetrical; median lobe subparallel-sided on apical part, rounded on basal part, broadly excavated longitudinally, with a small and trapezoid extension at apex, basal foramen projected ventrally, its apical margin with a pair of short projections, basal margin strongly projected to form a crescent lobe, basal bulb with a large and ovoid membranous part and elongate sclerite at center of membranous part.

Female. unknown

Remarks. This species is allied to the Japanese species, D. fossulatus Sharp and D. ispartae (Karaman), but the new species differs from the others by the mid trochanters each with a long and truncate spine and the mid tibiae each with two small denticles on the posterior side.

Distribution. Southern Korea (Chejudo Is.).

Holotype: male (deposited in Kÿungpook Nat. Univ.), Orimok, Mt. Hallasan, Chejudo Is., 20. v. 1990,
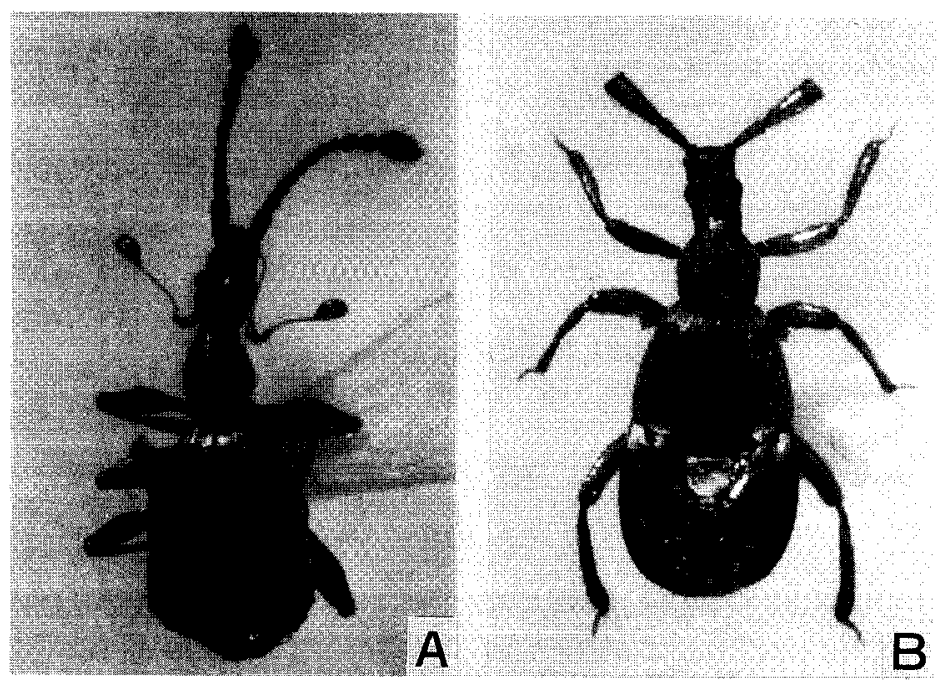

Fig. 11. A, Dicentrius sp., female; B, Diartiger dentipes sp. nov., male. 

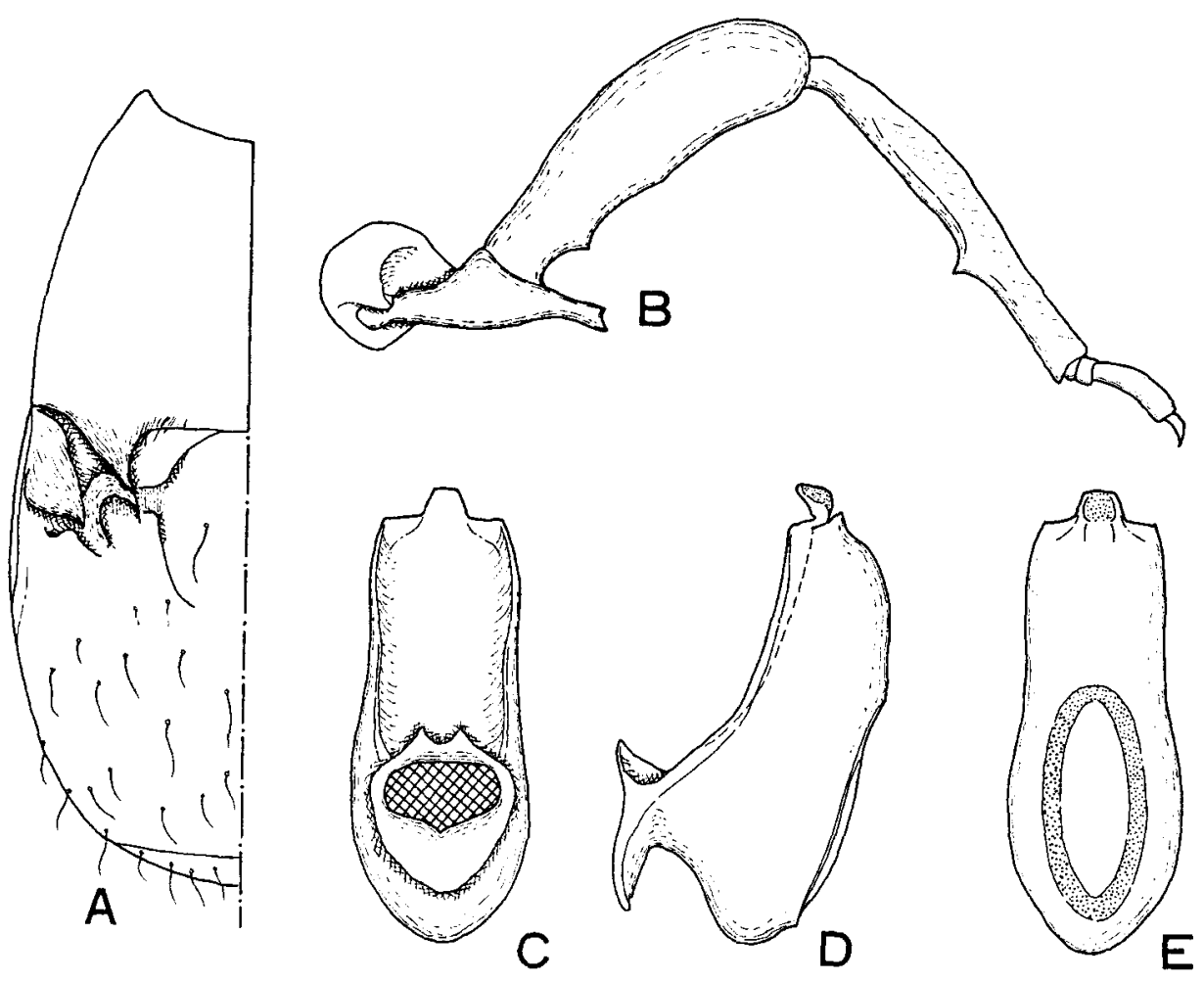

Fig.12 Diartiger dentipes sp. nov., male. A, elytra and abdomen, left side; B, mid leg; $\mathrm{C}$, male genitalia in ventral view; $\mathrm{D}$, ditto, in lateral view; $\mathrm{E}$, ditto, in dorsal view.

S. Nomura leg. Paratype: 1 male, same data as holotype.

\section{Acknowledgements}

We wish to express our hearty thanks to Director Culator Yoon Kee Kim, Senior Researcher Seong Jin Kang and Researcher Sei Ho Jung of Cheju-do Folklore and Natural History Museum, for their kind help on our collecting trip on Chejudo Island. Our cordial thanks are due to Prof. Katsura Morimoto and Associate Prof. Osamu Tadauchi of the Entomological Laboratory, Faculty of Agriculture, Kyushu University for his continuous guidance and valuable advices. We are also much indebted to Associate Prof. Michitaka Chûjô of Hikosan Biological Laboratory, Kyushu University for his kind help and advices in various ways for this work. 


\section{REFERENCES}

Besuchet, C., 1961. Revision des Pselaphostomus et Pselaphogenius ibérique (Col., Pselaphidae). Eos, 37(3): 229-265.

- 1974a. 24 Familie: Pselaphidae. In Freude, H. et al. eds., Käf. Mitteleurop., 5: 305-362.

- 1974b. Les psélaphides cavernicoles de l'Espagne (Coleoptera, Pselaphidae). Misc. Zool, Barcelona, 3(4): 41-68.

- 1991. Révolution chez les Clavigerinae (Coleoptera, Pselaphidae). Rev. Suisse Zool., 98(3): 499515 .

Chandler, D. S., 1988. A cladistic analysis of the world genera of Tychini (Coleoptera: Pselaphidae). Trans. Amer. ent. Soc, 114: 147-165.

Cho, P. S., 1957. A systematic catalogue of Korean Coleoptera. Humanities and Sciences, Korea Univ., 2: 173-338. (In Korean.)

— 1958. Revision des Psélaphides du Japon. Mém. Mus. Hist. nat., Paris, (Ser. A, Zool.), 18:1138.

Karaman, Z., 1953. Über neue Coleopteren aus Jugoslavien, Insbesonders aus Mazedonien. Act. Mus. Macedonici sci. nat., Skopje, 1: 91-116.

- 1954. Weitere Beiträge zur Kenntnis der Mazedonischen Coleopteren-Fauna. ibid., 2: 65-91.

Kurbatov, S. A., 1990. To the knowledge of the pselaphid beetles (Coleoptera, Pselaphidae) of Yakutia and Far East. Rev. Ent. URSS., 69: 71-78.

Löbl, I., 1964. Neue Pselaphiden Gattung (Coleoptera) aus Ost-Asien. Annot.Zool. Bot., (5): 1-5.

- 1968. Beitrag zur Kenntnis der Scaphidiidae und Pselaphidae von Korea (Coleoptera). Ann. Zool.,Warszawa, 25(9): 419-422.

- 1973. Beitrag zur Kenntnis der Pselaphidae (Coleoptera) der Koreanischen Voksdemokratischen Republik, Japan und des Ussuri-Gebietes. ibid, 30(9): 319-334.

1974. Beiträg zur Kenntnis der Pselaphidae (Coleoptera) der Koreanischen Voksdemokratischen Republik. Acta Zool. Cracoviensia, 19(5): 91-104.

1975. Beitrag zur Kenntnis der Pselaphiden von Korea (Coleoptera). Ann. Hist.-Natur. Mus. oat. Hungarici, 67: X3-118.

1977. Weitere Pselaphidae (Coleoptera) von der Korean\&hen Volksdemokratischen Republik. Bull. Acad. Polonaise Sci., Ser. Sci. Biol., 25(4): 235-241.

Newton, Jr., A. F. \& D. S. Chandler, 1989. World catalog of the genera of Pselaphidae (Coleoptera).

Field. Zool., 53: 1-93.

Nomura, S., 1991. Systematic study on the genus Batrisoplisus and its allied genera from Japan (Coleoptera, Pselaphidae). Esakia, Fukuoka, (30): l-462.

Raffray, R., 1904. Genera et catalogue des Psélaphides. Ann. Soc. ent. Fr., 73: 1-400.

- 1908. Coleoptera. Fam. Pselaphidae. In Whytsmann, P., ed., Gen. Zns., 64th fasc., Rome, 487pp. 1909. Nouvelles éspeces de Psélaphides. Ам. Soc. ent. Fr., 78:15-52.

1911. Pselaphidae. In Schenkling, S., ed., Coleopt. Cat., pars 27. W. Junk, Berlin, 222 pp. 